\title{
Tracking the Pathways of Education in Malaysia: Roots and Routes
}

\author{
Ong Puay Liu ${ }^{1}$, Sivapalan Selvadurai ${ }^{2}$, Badariah Saibeh ${ }^{1}$, Marsitah Mohd Radzi ${ }^{3}$, Shazlin Amir Hamzah ${ }^{1}$ \& Ong \\ Puay Hoon ${ }^{4}$ \\ ${ }^{1}$ Institute of Ethnic Studies (KITA), Universiti Kebangsaan Malaysia, Bangi, Selangor, Malaysia \\ ${ }^{2}$ Faculty of Social Sciences and Humanities, Universiti Kebangsaan Malaysia, Bangi, Selangor, Malaysia \\ ${ }^{3}$ School of Social Sciences, Universiti Malaysia Sabah, Kota Kinabalu, Sabah, Malaysia \\ ${ }^{4}$ Faculty of Medicine and Health Sciences, Universiti Malaysia Sarawak, Kuching, Malaysia \\ Correspondence: Ong Puay Liu, Institute of Ethnic Studies (KITA), Universiti Kebangsaan Malaysia, Level 4, \\ Administration Building, Kolej Keris Mas, 43600 Bangi, Selangor, Malaysia. Tel: 60-3-8921-3612. E-mail: \\ puayliu@yahoo.com
}

Received: March 22, 2013 Accepted: May 31, 2013 Online Published: August 1, 2013

doi:10.5539/ass.v9n10p93 URL: http://dx.doi.org/10.5539/ass.v9n10p93

\begin{abstract}
Education and the schooling system in Malaysia are constant agenda in the discourse of nation-building. This is because education is regarded as an important avenue to inculcate national consciousness and social cohesion among the people. This article attempts to track the various school systems in Malaysia, with the purpose to highlight the different routes of educational choices in Malaysia. These different routes have their roots in the education policies formulated through time and the growth of a multi-ethnic population in the country. It is argued that these different routes of educational choices display 'inclusiveness', catering to the needs of the diverse population of Malaysia - ethnic, language, religion, regional, disability, vocation, public or private. The Malaysian education scenario represents a complexity of choices, each colouring the pathways of educational experience, expertise and engagement. The guiding question is to what extent this complexity of educational routes influence social cohesion?
\end{abstract}

Keywords: $1 \mathrm{R}+3 \mathrm{r}$, education, cultural diversity, social cohesion, social inclusion, national unity

\section{Introduction}

Education for social cohesion; education for national unity; education for integration - whichever phrase is used, the intent is clear. Education is an important institution for promoting unity, common citizenship and solidarity amongst its citizens of diverse backgrounds. In the context of a plural society, the role of education as a prime mover of change towards more meaningful relationships is pertinent as these meaningful relationships will lead to better social order, respect and peace in the country. However, the question that comes to mind is, how do we achieve such goals? What kind of education and education system should we have to allow us to achieve our goals, or to enable education to play its role in promoting social cohesion, unity or integration, especially so for a plural or multi-ethnic society?

These questions are by no means easy to answer. Education is such an important but complex institution in society that impacts on the lives of its people. The aims of education centre around the local conditions and aspirations. The case of the 15-year old Pakistani schoolgirl, Malala Yousufzai, who was shot at close range in an assassination attempt by Taliban gunmen on 9 October 2012 while returning home on a school bus (Wikipedia, 2012) for being an ardent advocate for girls' right to education, serves as a poignant reminder of the contradictions and tensions surrounding who should get what kind of education, why, when, where and how.

This article focuses on the education system of Malaysia, with particular attention on the persisting discourse juxtaposing the need for a one-school, one language education system as a way to achieve national unity or social cohesion with the continued existence of vernacular schools seen as hindering the achievement of this national goal. The article argues that the Malaysian education scenario includes not only the national schools and vernacular schools, but many other types of schools. Hence, this article attempts to track the various routes of educational choices in Malaysia, with the purpose to illustrate the availability of different school systems. These different routes and choices have their roots in the education policies formulated through the passage of time and 
the growth of a multi-ethnic population in the country. It could be argued that these different 'routes' of educational choices display 'inclusiveness', catering to the needs of the diverse population of Malaysia whether by ethnic, language, religion, regional, disability, vocation, public or private. The Malaysian education scenario represents a complexity of choices, each colouring the pathways of educational experience, expertise and engagement.

The article will begin the discussion with the education system in Malaysia, taking into account the past and present scenarios. The second section will be a discussion on key concepts, that is, education, social cohesion and national unity. The third section will describe the availability of various routes of educational choices to substantiate the argument that the Malaysian education discourse goes beyond the national-vernacular polemic. The final section will summarise the salient points discussed in the paper.

\section{Education in Malaysia}

Cheeseman, who was Education Director for the Federation of Malaya in the 1940s, wrote in his Foreword for Chelliah's book: "Someone has said that if we ignore the Past, we cannot understand the Present or forecast the Future" (Chelliah, 1947: v). Knowing the past is important for us to know the roots of our current situation as well as to identify the causes or conditions that have given rise to such situation.

As a 'plural society par excellence', the Malaysian government has, through the years since independence, strived to produce an education system that balanced the goal of nation-building with the needs of the diverse population. As early as 1940, for example, at a time when Malaya was still under British rule and on the brink of Japanese colonisation, there were research done on the educational problems of the Straits Settlements and on the role of education for unity in Malaya then. We present here two theses written on this subject but which held opposing viewpoints.

Chelliah submitted his thesis titled 'A History of the Educational Policy of the Straits Settlements with Recommendations for a New System based on Vernaculars' for the Degree of Doctor of Philosophy to the University of London in 1940, which was subsequently published in 1947. Chelliah brought to attention the multi-ethnic population of the Straits Settlements (S.S): The presence of not only different racial-groups but also language-groups, and the fact that a large percentage of the population are still immigrants, involve the existence of different stages of development among the population, and as a corollary, varying needs. These in turn lead to problems as to the types of schools and curricula best suited to meet these differences. ... To deal satisfactorily with all the issues raised above and to prepare any unified scheme of education for the Colony, it will be well in the first place to trace the history of educational policy from the beginning of last century, and to study its underlying causes (Chelliah, 1947: 8-9). Chelliah stated that two reasons motivated him to do research on the Educational Policy of the Straits Settlements: (i) he was never satisfied with the beginning of a child's education in a language which was not his mother tongue, and he was curious to know how it came about that in Malaya, this rather unnatural and unsound method was ever adopted; and (ii) repeated comments from more than one quarter that Asiatic teachers were perhaps good enough to cram for examinations, but not good enough to make any original contributions to the advance of Education in Malaya (Chelliah, 1947: iii). Hence, quoting Winstedt, Chelliah reasserted that 'any ideal of education, not adjusted to local wants, must lead to economic dislocation and social unrest (Chelliah, 1947: 141).

Taking into consideration the general aim of education to be the fullest development of individual personality in harmony with the society or community of which the individual is a member, Chelliah noted that the individual's self-development can only be realised in and through the society through which he is a member. The inter-relations between the individual and society are to be found mainly in social intercourse and in the work that men do, for the work that the individual does is part of the work of society. Society as it exists and the work done by individuals have their roots in the past. It is necessary, therefore, to keep before us the common heritage of the society we are considering. It would be wrong to attempt to build a form of society that is fundamentally alien (Chelliah, 1947: 141). As such, Chelliah asserted that the educational system that we build must take account of diverse needs, depending on the differences of race, of language, and of social custom. Only by preserving that which is vital and deeply personal in individual and social life can real harmony be secured. The history of India, as well as that of Malaya, has proved that races live together best when their cultural patterns are preserved and their traditions respected (Chelliah, 1947: 141). In line with his principle on the importance of respecting the individual and his society, Chelliah advocated for the importance attached to the study of the vernaculars, for it is maintained that a people expresses its true self through his mother-tongue (Chelliah, 1947: 142). He further went on to say that vernacular education means, however, more than a cursory study of the vernacular; it means education in and through the vernacular. While passionately asserting the importance of 
mother-tongue and advocating for vernacular education, Chelliah also acknowledged the necessity for a common language for all, especially in respect to the presence of a polyglot population (Chelliah, 1947: 142).

Ho Seng Ong did a thesis on the education system of British Malaya for his Degree of Doctor of Education at the University of Denver, USA in 1949. His thesis was published as a book in 1952 titled Education for Unity in Malaya: An Evaluation of the Educational System of Malaya with Special Reference to the Need for Unity in its Plural Society. Ho began his introductory chapter with the section titled 'What is wrong with Malaya'; followed by 'Shortcomings of Malayan Education'. At the outset, Ho gave the reason why he ventured to publish his thesis as a book: It is in the hope that all classes and groups in Malaya would support the non-communal school system because that would be good for the country and would weld all Malayans together into a united nation that I venture to publish this book of mine (Ho, 1952: vii).

Corresponding to Chelliah's observation on the complexities of the education system of Malaya, Ho also theorised that any analysis and understanding of the development of the education system of Malaya had to be seen in the context of its plural society (Ho, 1952: 9), or more specifically with regards to the role of education in promoting national unity in the Malayan plural society, His Statement of the Problem was An evaluation of the educational system of British Malaya with special reference to the need for unity in its plural society (Ho, 1952: 7). Towards this objective, Ho made two assumptions: (i) the first assumption referring to the major political objective of a united Malaya preparing for eventual self-government; and (ii) the second assumption referring to the Malayan plural society and the need to diminish the plural character of our Malayan life so that the gulf separating the different races and groups and interests should be narrowed and eventually bridged (Ho, 1952: 7-8). Ho further gave the observation of an Englishman who had lived and worked for many years in Malaya: Malaya should no longer be a land of Malays and Chinese and Europeans and Indians but a land of Malayans; Malayans with a common will, born of a common suffering, to demonstrate in that part of the world the dynamic of a new ideal (Egmont Hake quoted in Ho, 1952: 8).

In his Preface, Ho wrote that there had been several reports and studies on the educational problems, and that there had been considerable discussion both in the press and council rooms and committees on our educational objectives and means to achieve those ends (Ho, 1952: v). Ho highlighted the concern regarding the urgent need for our schools to serve as a unifying agency in our mixed population (Ho, 1952: v). Ho also asserted that in a country like Malaya the education of the young must assume tremendous significance ... and that schools can, as no other single social institution is able to, weld the different races together. However, to accomplish this worthwhile objective, children must not be separated into different racial or language schools. Instead, they must be brought together to intermingle with one another ... and be able to grow up as Malayans first and foremost (Ho, 1952: v). In line with this principle, Ho advocated for non-communal school system, which he strongly felt to be the country's nursery for the building up of our Malayan nation (Ho, 1952: vi). This non-communal school system would provide for an intermingling of the races, facilitating easy development of friendships that know no barriers of race, religion, language, culture and class (Ho, 1952: v). Such schools would therefore serve as the best and most effective place to begin practising good citizenship. What kind of common language did Ho advocate for his non-communal school system? For him, it was the English schools, that is, schools using English as the medium of instruction. Ho noted that in English schools, Malay, Indian, Eurasian and Chinese boys and girls mixed naturally and easily. These ties formed during school days were carried on to adult life (Ho, 1952: v).

Writing in his Foreword for Ho's book (1952: Foreword), Thuraisingham, Member for Education, Federation of Malaya, noted that Ho's critical observations of the slow progress of education in Malaya were amply justified by records. Nevertheless, Thuraisingham also noted that these observations might offend some persons, and that Ho's conclusions, though logical, were in some respects unsuitable to the religious and racial diversity of Malaya.

Undoubtedly, the present education system in Malaysia has its origins in the pre-Independence era. The British introduced secular education and established the first English school in Pulau Pinang in 1816. Other schools, classified according to the language of instruction, were the Malay, Chinese, and Tamil schools. By 1938, there were 788 Malay schools, 654 Chinese schools, 607 Tamil schools, and 221 English schools. These schools had diverse management and financial resources. They included government-maintained schools, missionary schools, and non-profit schools, all of which received financial aid from the government, as well as privately funded schools (UNDP, 2009; Ong \& Roovasini, 2010).

After the Second World War (1941-46), there was a significant change of attitude towards education among all ethnic groups, which led to an increase in demand for education. This demand was attributed to the increasingly 
settled position of the immigrants (in part due to post-war developments in China, India, and other neighbouring countries) and the emergence of Malay nationalism (UNDP, 2009).

On the eve of independence, the necessity of nation-building and the centrality of education to that project was clear both to the British colonials of Malaya and the new elites preparing to take over administration of the country (Brown, 2005). The British government intended an education policy which would be relevant to the political and socio-economic goals of the people, Malaya's three principal ethnic minorities - Malays, Chinese and Indians.

A number of studies and reviews were carried out to decide on the policies and principles to be followed with regard to education: a Central Advisory Committee on Education set up in 1949; a committee on Malay education which produced the Barnes Report in 1951; and a study on Chinese education which produced the Fenn-Wu Report in 1951 (UNDP, 2009).

The Barnes Report recommended a national school system, which would provide primary education for six years in Malay and English, hoping that over a period of time, the attraction to have separate schools in Chinese and Tamil would wane and disappear. The reaction of the Chinese community to the Barnes Report was not totally positive. While the community agreed with the basic recommendation that Malay be treated as the principal language, it felt that there should be some provision to recognise Chinese and Tamil as important components of a new definition of Malaya's national identity. To pacify ethnic sensitivities, the British government approved a modified formula that would allow bilingualism in Malay schools (Malay and English) and three language 'solution' in Tamil and Chinese schools (either Tamil-Malay-English or Chinese-Malay-English) by recommending a common curriculum for all schools, hoping that a national school system would evolve (Wikipedia, 2009). The Barnes Report stated explicitly that its approach was governed by the belief that the primary school should be treated avowedly and with full deliberation as an instrument for building up a common Malayan nationality. These words were echoed by the Fenn-Wu Report which noted that it was only natural that Malaya's educational policy should be directed consciously and consistently toward ... an ultimate Malayan nation. However, the Barnes Report recommendations were aimed at the creation of a national public school system based on bilingual education with the particular promotion of a national lingua franca - either Malay or English. The implication of the Barnes Report was that 'Chinese and Indians are being asked to give up gradually their own vernacular schools, and to send their children to schools where Malay is the only oriental language taught. The Fenn-Wu Report on Chinese education took the opposite approach to the Barnes Report, recommending the continuation of own-language schools (vernacular schools) with Malay and English to be taught alongside (Brown, 2005: 4 \& 5). A consideration of these reviews led to the Education Ordinance in 1952.

The Barnes Report was unsuccessful, and in 1955, two years before Malaya's independence, the Razak Report endorsed the concept of a national education system based on Malay (the national language), being the main medium of instruction (Wikipedia, 2009). In 1956, a third committee report on education, chaired by the Abdul Razak bin Hussein, who later became Malaysia's second Prime Minister, proposed that vernacular education was to be allowed to continue both at primary and secondary level, but that a common curriculum be instituted. The Razak Report introduced the use of the Malay language as the national language and as a compulsory subject in primary schools (in addition to the English Language), and the use of a common syllabus for all schools. Proposals made in the Razak Report were enacted in the Education Ordinance 1957 and the National Education Policy was formulated. The Razak Report allowed for the transition from a fragmented colonial education system to one which was more integrated along national lines. A later review of the education policy, however, saw the languages both of instruction and examination in secondary schools restricted only to Malay or English. Existing Chinese-language secondary schools were faced with the hard choice of switching to one of these languages or losing any government assistance (Brown, 2005: 5; UNDP, 2009).

In 1960, a committee was set up to review the implementation of the education policy. The Rahman Talib Report made several recommendations which were subsequently incorporated into the Education Act 1961. These included the abolishment of school fees at primary level (implemented in 1962), the use of Bahasa Malaysia as the main medium of instruction, and automatic promotion to Form 3, thus increasing basic education to 9 years. Universal education was raised to 11 years in 1979 based on the recommendations of the Cabinet Committee Report on Education. The report also gave emphasis to school curriculum to ensure the acquiring of the $3 \mathrm{Rs}$ (reading, writing, and arithmetic) at the primary level. In 2003, primary schooling was made compulsory under the Education Act 1996 (UNDP, 2009).

According to the Education Development Master Plan (2001-2010), the aim of the National School Curriculum is to provide opportunities for quality education to all Malaysians from preschool to tertiary level in terms of 
access, equity, quality, efficiency and effectiveness of education management. The role of education at all these levels is said to develop the child fully (intellectual, spiritual, emotional and physical [JERI]); inculcate and develop desirable moral values; transmit knowledge; create a united Malaysian citizen; and produce trained manpower. This aim to create a united Malaysian citizen among her constituent ethnic groups, namely, Malays, Chinese, Indians, orang asli, and natives of Sabah and Sarawak has led to the government introducing on a national scale a common school system, common curriculum content, common public examinations and the use of Bahasa Malaysia as the main medium of instruction (Mukherjee \& Singh, 1983). Indeed, the National Education Philosophy of Malaysia lends credence to the government's nation-building aspiration through the education system. The National Education Philosophy reads thus:

Education in Malaysia is an on-going effort towards further developing the potential of individuals in a holistic and integrated manner, so as to produce individuals who are intellectually, spiritually, emotionally and physically balanced and harmonious, based on a firm belief in and devotion to God. Such an effort is designed to produce Malaysian citizens who are knowledgeable and competent, who possess high moral standards, and who are well responsible and capable of achieving high level personal well-being as well as being able to contribute to the harmony and betterment of the family, society and nation at large.

However, with the introduction of the concept of National Key Result Areas (NKRA), and Key Performance Indicators (KPI) in 2009, the role of education to produce trained manpower seems to have taken precedence over the other desirable goal of the education system - to develop the child fully, inculcate and develop desirable moral values, transmit knowledge and create a united Malaysian citizen. Instead, the Malaysian government has made education one of the priority areas to bring about broader reforms to the National Education System over time (Tan Sri Dato' Haji Muhyiddin bin Mohd Yassin, Minister of Education, quoted in Pemandu, 2010: 150). The aspiration of the Education NKRA is to improve student outcomes across Malaysia's school system and to enable access to quality education for all students. Improving student outcomes is crucial to developing a more competitive workforce as Malaysia pushes towards becoming a developed nation by 2020. Making quality education more accessible will ensure more Malaysians gain the chance to improve their standard of living. In addition, resources would be used effectively to deliver improved outcomes and divided equitably between schools of different educational standards to benefit all students irrespective of their starting point. This equitable division would allow all students to gain the basic skills required to be a productive member of society while also providing the opportunity for exceptional students to realise their full potential (Pemandu, 2010: 151).

The latest in the successive formulation of education reports, master plans and blueprints, is the recently released Preliminary Report: Malaysia Education Blueprint 2013-2025 on September 11, 2012 by the Ministry of Education. This Blueprint is the latest attempt by the government to improve the education system so as to achieve its objectives of nation building, capacity building, and at the same time, responding to the aspirations of the people While lauded as timely, the Education Blueprint has nevertheless received many comments and criticisms, especially regarding the government's vision on the creation of a Malaysian nation through education, and the continuity of multi-lingual education. Arumugam (2012), for example, asserted that the Report has overlooked an unintended consequence, which is that the blueprint would result in marginalising and destroying multi-lingual education and pose threats to the continued cultural sustainability of our multi-cultural nation. According to Arumugam, the vision to create national unity through education requires broad and clear thinking. It cannot be achieved when we are fuzzy about national unity and/or education.

Fifty years on since the publication of Chelliah's and Ho's books in 1947 and 1952 respectively, and the various educational policies and blueprints of the Malaysian government through the years, our inheritance of the educational problems in then British Malaya is still haunting us. The challenging discourse continues to revolve around the issue of the status of vernacular schools and national schools, i.e. one-language school system versus multi-language school system, and what kinds of schools get to be defined as 'national' schools? As Ramon Navaratnam noted, the Blueprint misses the opportunity to ensure an inclusive educational system (Ramon Navaratnam, 2012) in setting the parameters for the various school systems to receive due recognition in terms of fund allocation, infrastructural development and national status.

With such educational legacy and status of current education system, how then can education in Malaysia play its role in producing children with full potential developed, who will blossomed into good citizens, and able to relate (1R), recognise, respect and reconcile (3r) with fellow citizens? In a multi-ethnic, multi-cultural, multi-religious and multiregional country like Malaysia, building relationship skills through education provides the foundation for our young generation to establish social relationships through the process of adaptation, accommodation and acceptance of differences and variations in ways of thinking, speaking and acting. Political 
theorists concerned with multicultural societies broadly concur that education, especially the fields of citizenry and history, plays a vital role in promoting good inter-ethnic relations, but quite what form this education should take is a matter of dispute (Brown, 2005: $3 \& 8$ ).

\section{Defining Concepts and Conceptualisation}

\subsection{Education}

As Ramon Navaratnam (2012) asserted in his comments on the Education Blueprint, we need boldness and innovation from a critical but constructive dimension to ensure that our educational policy, its implementation and institutions bring out the best in our children to develop their full potential to serve the common good of this nation. However, the task of defining education is not easy and most writers focused on the purpose or objectives and roles of education. A working definition is necessary to put into context a common understanding of what education is, so as to allow decision makers and implementators to share the same viewpoint. A review of the various government education reports and policies substantiates the absence of a definition on education. For example, the latest document on education released by the Malaysian government on September 2012 - the Education Blueprint - also does not give any definition on the meaning of education. The emphasis in the government reports is more on what education can do in terms of nation building and human resource development for Malaysia, as illustrated by this statement: Specifically, education is perceived as promoting national unity, social equality, and economic development. Education is an instrument for promoting and strengthening national integration by inculcating a common and shared destiny among the different ethnic groups, removing racial prejudices and encouraging cultural tolerance, and establishing the use of a common national language, that is, Bahasa Malaysia. As an agent of social equality, education is to promote social consciousness and social justice by providing equal educational opportunities. Education is seen as a means for social mobility which forms one of the avenues for income redistribution and restructuring the Malaysian society economically. The education system has an important role to play in supplying human resources for economic growth. Besides economic prosperity, the schools are to help in developing a caring society (Lee, 1999: 87).

The word 'education' literally means 'to bring forth' (Ong, 2008: 8). Etymologically, the word education is derived from educate (Latin), 'bring up', which is related to educate 'bring out', 'bring forth what is within', 'bring out potential' and ducere, 'to lead'. Education in the largest sense is any act or experience that has a formative effect on the mind, character or physical ability of an individual. In its technical sense, education is the process by which society deliberately transmits its accumulated knowledge, skills and values from one generation to another (Mumbai University, 2012). It indicates that the true task of this process is to draw forth from the mind its innate potential to understand things. In the name of education the students are passed through courses of standardised instruction intended to make them efficient servants of an alienated social system.

This brings to mind Freire's (1972) thesis that the mainstream education system concentrated on the 3Rs reading, writing, arithmetic - with students acquiring the ability to 'read the word' but not the ability to 'read the world', that is, an education based on the real experiences of social interaction and relationships (1R component) of the students. Today's educational system, hijacked by the demands of the State and Market, aggravates the task of teachers in carrying out their responsibilities efficiently and effectively (to the extent that the Education Blueprint singled out the quality of teachers and teaching as one of the main contributing factors to the decline in student achievement and education standards). Hence, in this article, education refers to the process of bringing forth/nurturing the potential in students, by sharing with them the knowledge, skills and values of what is good or bad, acceptable and not acceptable. The purpose of education is thus to mould the character of students so that they will be equipped with the ability to distinguish between good and bad, desirable and undesirable, acceptable and unacceptable in the society in which they are members.

\subsection{Social Cohesion and National Unity}

Ho (1952: 8-9) had listed several topics and questions which required some answers: education and unity; education for social cohesion; and issues pertaining to the educational system. However, Ho did not define social cohesion, apart from stating its importance in a plural society. Reference to the connection between education and social cohesion was mentioned 11 years before Ho's study - in 1941 by Havighurst, an American educator. Havighurst noted that education is generally understood to be an instrument of social policy - to realise our social ideals, and that education is used to promote social cohesion (in Ho, 1952: 94). Several decades later, researchers are still writing about social cohesion, perhaps more so in this age of globalisation, increasing international migration and emerging diversities as well as disparities. As Chan \& Chan noted, given the growing cultural and ethnic diversity in society, the challenges of globalisation, widening disparity between the rich and poor, new forms of exclusion, political threats and social insecurity, as well as a handful of other problems, it is 
easy to understand the concerns that policy makers have with regard to social unrest and governance issues. It is therefore no coincidence that policy makers have found the concept of social cohesion - of people sticking together in the face of difficulty - an increasingly attractive objective (Chan \& Chan, 2006a: 635-636).

In Malaysia, the term social cohesion is fast gaining ground, as some sections of the society are keen to know what makes Malaysia work, in spite of its plural society and the frequent reports of tension among people of different ethnic, religious and cultural backgrounds in the mass media. According to Shamsul, many researchers studying ethnic relations in Malaysia are preoccupied with the conflict paradigm, consequently, using it as an analytical tool to understand and evaluate every single problem or tension perceived to exist in society (Shamsul, 2012: 16). Such perceived existence of persisting ethnic tensions could be due to the way unity is being conceived by policy makers and the people. The phrase 'unity-in-diversity' has become a cliché in Malaysia without a clear understanding among the people of what it means and how to achieve this. As Shamsul noted, unity in diversity has become a mantra in the everyday life of Malaysians, without asking what it means, and the sincerity of policy makers in realising this dream (2012: 2).

The answer according to Shamsul, requires a shift in sociological imagination, from one based on 'unity' to one based on 'cohesion' (Shamsul, 2012: 3). Unfortunately, Shamsul did not offer a working definition of cohesion, apart from mentioning that cohesion is a social phenomenon anchored on a deep aspiration for unity, which consequently encourages members of a society to initiate efforts and activities that could be termed as prerequisites for unity. The sum total of these efforts will engender peace, harmony and stability in the society, however, not quite achieving the aspired unity yet (Shamsul, 2012: 3-4).

What then is social cohesion? Chan \& Chan (2006a: 635), Markus \& Kirpitchenko (2007: 21), Acket et.al (2011: 3 ), among others, have noted the numerous researches and writings on social cohesion. For example, Markus \& Kirpitchenko (2007: 21) wrote that social cohesion as a concept has a long tradition in academic enquiry and occupies a central place in traditional sociological debate on the role of consensus versus conflict in society. Chan \& Chan reported that the concept of social cohesion has been popular among policy makers and international regimes in Western democratic societies since the 1990s. However, despite the prevalence of the notion of social cohesion among many governments and international regimes, it is surprising that it still lacks a commonly agreed definition (Chan \& Chan, 2006a: 635).

The dictionary defines cohesion/cohere as to stick together, to hold together in a mass that resists separation; to hold together to form a whole. This meaning of cohesion suggests that cohesion refers to a state in which different components 'stick' or hold together to form a coherent, orderly and meaningful whole. According to Markus \& Kirpitchenko (2007: 25), most current definitions of social cohesion dwell on the intangible, such as common values, sense of belonging, attachment to the group, and willingness to participate and share outcomes. They have summarised the commonalities and differences in current definitions of social cohesion. The commonalities are:

1) a shared vision: social cohesion requires universal values, common aspirations or identity shared by their members.

2) a community or group: social cohesion tends to describe a well-functioning core group or community in which there are shared goals and responsibilities and a readiness to cooperate with other members.

3) a process: social cohesion is generally viewed not simply as an outcome, but as a continuous and seemingly never-ending process of achieving social harmony.

The differences concern the factors that operate to enhance (and erode) the process of communal harmony, and the more complex issue of the relative weight to be attached to the operation of those factors. Differences in approaches are also found in the way social cohesion is treated as a cause or effect, that is, as an independent or dependent variable of the societal analysis (Markus \& Kirpitchenko, 2007: 25-26).

With the foregoing discussion on unity as an ideal aspiration, and social cohesion as a process, but both requiring some common bases as prerequisites, such as shared vision and common values, trust and responsibility, sense of belonging and inclusiveness, mutual help and cooperation, justice and equality in all spheres of life (economic, political, socio-cultural), how then can education play a role as an instrument of social policy to facilitate these characteristics and elements among students?

With this framework on social cohesion in mind and the focus on education for social cohesion, the following section will present the various routes of educational choices in Malaysia, with the purpose to illustrate the availability of different school systems. The guiding question is to what extent this complexity of educational routes contribute to social cohesion? With this existing educational structure, how then can we create 
opportunities for these different school systems to play their role in enabling the $1 \mathrm{R}+3 \mathrm{r}$ principle to flourish in the hearts and minds of their respective students, thereby enabling education to play its role in fostering social cohesion among the diverse communities?

\section{Educational Routes and Choices in Malaysia}

The various stages and processes of migration by land and sea over thousands of years have resulted in the 'plural society' (Wong \& Gwee, 1980: 2) or 'polyglot population' (Chelliah, 1947: 4) that marked Malaya of yesteryear, and Malaysia today. Consisting of Peninsular Malaysia, Sabah and Sarawak, the population of 28.3 million represents more than 70 ethnic groupings and many more sub-groupings, each identified by their respective location, dialect, cultural characteristics (Shamsul, 2012: 13) and also religion. It is essential to bear in mind this background of ethnic, cultural and religious diversity, including special needs children and socio-economic status.

With such diversity, it is no wonder that education was and still remains a contentious domain, with constant debate about its role as an instrument of change. Education's main vehicle, the school, provides the technical, conceptual and cultural skills that enable individuals to think of themselves as belonging to that fictive, invisible community called nation (Feinberg, 1998: 48). In the context of a plural society, the education and the school, besides acting as an avenue to bring forth the students' potential, have an equally important role to play in providing students from diverse cultures and needs with a common (national) identity, sense of belonging, and feeling of connectedness with members of the imagined nation (horizontal cohesion) as well as with the State (vertical cohesion).

This section will present the various routes of educational choices that confront Malaysian parents and children. From the lowest stage of education, the preschool, to the highest level of education, tertiary education, a variety of different schooling systems await the child, as illustrated by Figure 1 and Figure 2.

Figures 1 and 2 below show the variety of different educational systems in Malaysia, and their concomitant pathways of educational routes. At the primary and secondary school levels, we have the public and private schools; national and national-type schools; secular and religious schools; schools for orang asli communities of Peninsular Malaysia; boarding schools and day schools; academic and vocational/or technical schools; Mara junior science colleges and Chinese independent schools; special education schools; expatriate and international schools; as well as home schooling. At the university level, we have public and private institutions of higher learning. These varieties of schooling at the primary, secondary and tertiary levels provide a multitude of routes available for Malaysian students. The underlying question is that can all these different types of schools function as the country's nursery for the building up of a Malaysian nation (as envisaged by Ho in his 1952 thesis)? Can all these schools provide a conducive environment for the intermingling of students from different ethnic backgrounds, facilitating the learning of the different cultures and histories? Will these schools help to foster good citizenship values and encourage the students to be good citizens in their everyday lives? 


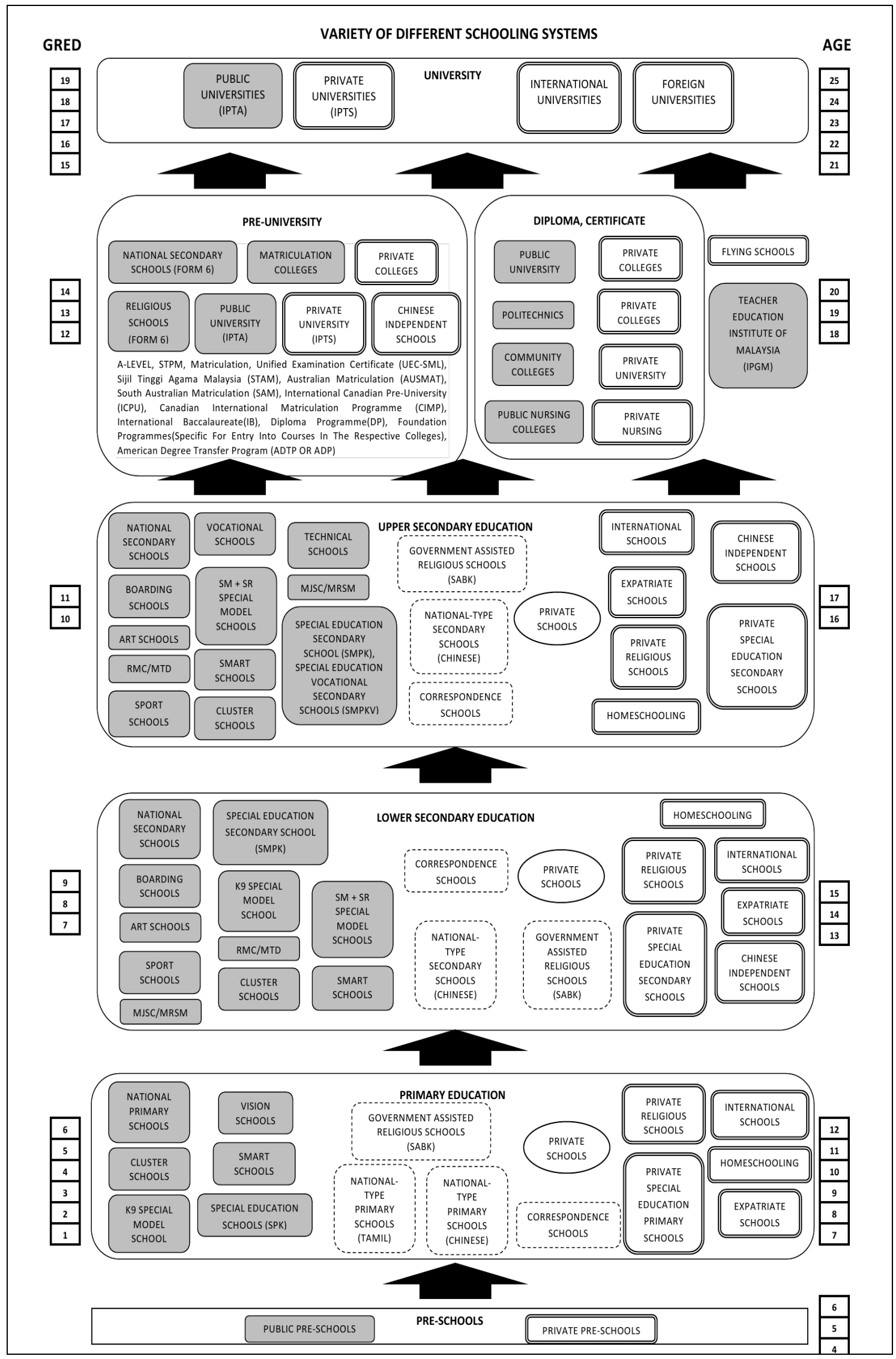

Figure 1. Variety of different schooling systems (adapted from Selvadurai, S., 2012) 


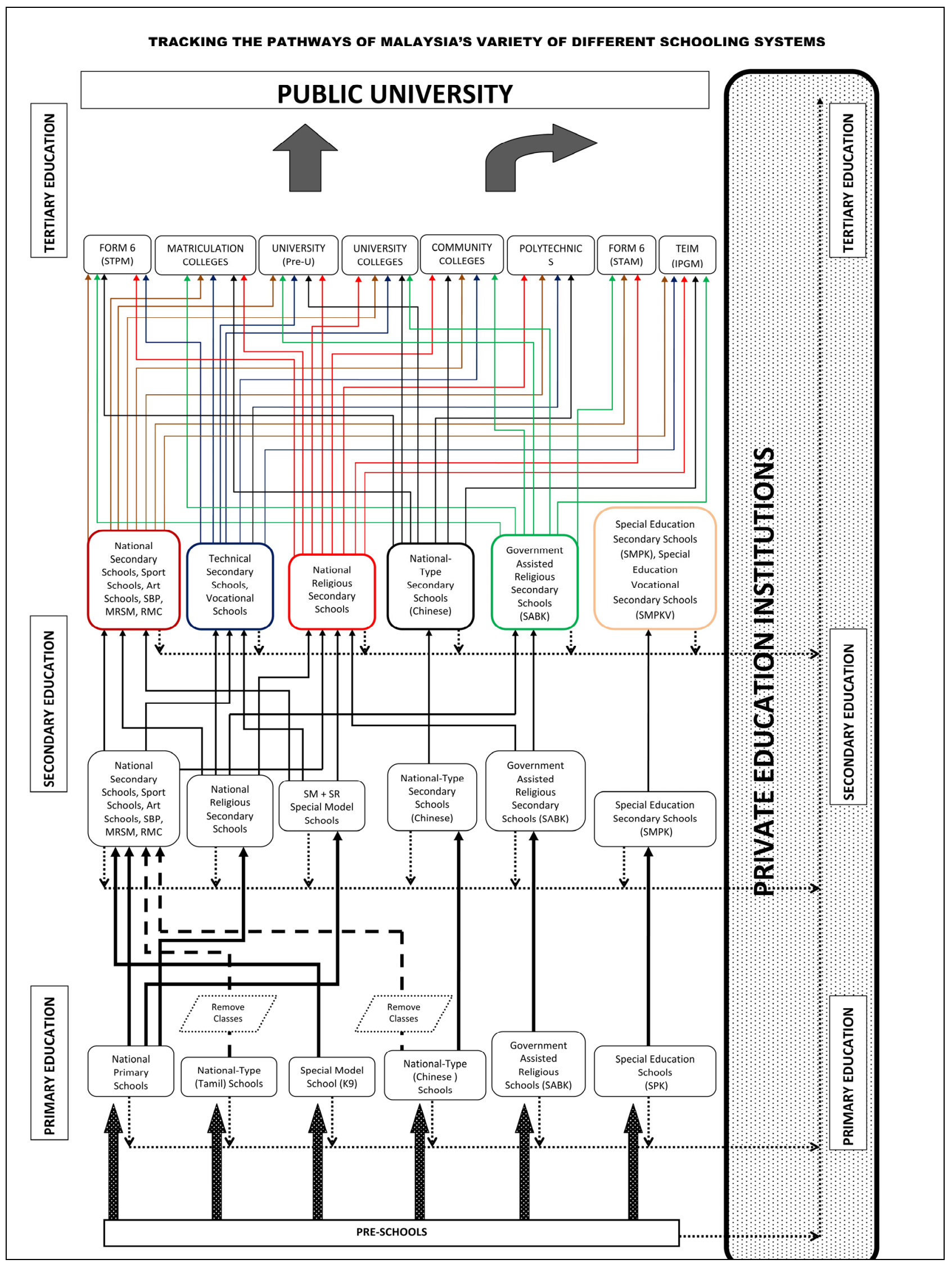

Figure 2. Tracking the pathways of Malaysia's variety of different schooling systems 


\section{Concluding Remarks}

Today's youths are a country's greatest assets, and education is one main sector where a country can ensure its young people are accorded the opportunity to develop their potential, skills and character, and consequently to function as responsible and useful citizens. Education not only teaches the individual to read, write and count $(3 R)$, but should also allow students to learn about their own history, culture, religion and, at the same time, the history, culture, religion of other ethnic groups in their own country and beyond. Such an inclusive education opens the minds of the students to the diversity and differences prevalent not only in human society but also the natural environment. It also trains the students to understand the genesis and development of diversity and to learn to adapt and accept such differences. With such training and understanding, students will gain an insight into how to live and relate respectfully with others of different colour, creed, customs, culture, religions, gender, educational level and economic status. This aspect of the purpose of education is what this paper would like to term as ' $1 R$ ' - relationship based on right knowledge, good understanding and moral values.

$I R$ and its corresponding $3 r$ values of recognising, respecting and reconciling differences, facilitate social cohesion to develop among students who study in the different school systems. The underlying principle is that, no matter which category of school they are studying in, the education they receive should enable them to develop the basic precepts of social cohesion, i.e. shared vision and common values, trust and responsibility, sense of belonging and inclusiveness, mutual help and cooperation, justice and equality, and be able to act accordingly, with fellow members of their own society as well as with larger society.

The availability of the variety of schooling routes in Malaysia (as presented in Figures 2 and 3) underscores the reality of the complexities of the educational system in Malaysia. Not only is there no one-language school system, but there are multi-category and multi-tiered school system (16 categories for primary level; 21 categories for lower secondary level; 22 categories for upper secondary level; 18 categories for pre-university, diploma, certificate level; and five categories for university level). Hence, as Lee aptly observed, what has been a firmly state-controlled education system has become liberalised to some extent; what used to be an elitist secondary education has become universalised; what used to be a highly centralised administrative system has been decentralised; and what used to be a single producer of education, that is, the state, has changed to "multiple producers" of education through privatisation (Lee, 1999: 95).

UNESCO, advocating for an Education for All (EFA) policy, emphasises that the overall goal of inclusive education is to ensure that school is a place where all children participate and are treated equally. This involves a change in how we think about education. Inclusive education is an approach that looks into how to transform the education system in order to respond to the diversity of learners. Strengthening links with the community is vital, where relationships between teachers, students, parents, and society at large is crucial for developing inclusive learning environments (UNESCO, 2010).

In the interest of education for social cohesion, and taking the reality of the variety of educational routes as presented above, it is imperative for the Malaysian government to take into consideration the people's aspirations and parental choices. Ramon Navaratnam's call for a more inclusive rethinking of the term 'national schools' is timely and pertinent, in view of the existence of multi-category schools - whether national or national-type, mission or religious, vocational or technical, residential or non-residential, MRSM or non-MRSM, matriculation or non-matriculation, private or public, foreign or local. How such multi-category schools existing in the Malaysian educational system can contribute to social cohesion is the question guiding the research on $1 \mathrm{R}+3 \mathrm{r}$ for social cohesion.

\section{References}

Acket, S., Borsenberger, M., Dickes, P., \& Sarracino, F. (2011). Measuring and Validating Social Cohesion: A Bottom-Up Approach. Working Paper No 2011-08. Retrieved January, 2011, from http://www.oecd.org/dev/perspectivesonlocaldevelopment/46839973.pdf

Arumugam, K. (2012). Blueprint marginalises multi-lingual education. Retrieved October 5, 2012 from http://www.malaysiakini.com/news/210857

Baharuddin, S. A. (2012). Modul Hubungan Etnik. Edisi Kedua. Bangi: Institut Kajian Etnik, UKM.

Brown, G. (2005). Making ethnic citizens: The politics and practice of education in Malaysia. CRISE Working Paper No. 23. pp. 1-18. University of Oxford: Queen Elizabeth House.

Chan, H. P. T., \& Chan, E. (2006). Reconsidering social cohesion: Developing a definition and analytical framework for empirical research. Social Research Indicators, 75, 273-302. Retrieved from http://www.springerlink.com/content/3637524558307405/fulltext.pdf

http://dx.doi.org/10.1007/s11205-005-2118-1 
Chan, J., \& Chan, E. (2006). Charting the State of Social Cohesion in Hong Kong. The China Quarterly, 187, 635-658. Retrieved from http://journals.cambridge.org/abstract S0305741006000415 http://dx.doi.org/10.1017/S0305741006000415

Chelliah, D. D. (1947). A History of the Educational Policy of the Straits Settlements with Recommendations for a New System Based on Vernaculars. Thesis approved for the Degree of Doctor of Philosophy in the University of London in 1940.

Delors, J. (1996). Learning: the treasure within. Report to UNESCO of the International Commission on Education for the twenty-first century. Retrieved from http://www.unesco.org/delors/delors_e.pdf

Freire, P. (1972). Pedagogy of the oppressed. Translated by Myra Bergman Ramos. Great Britain: Sheed \& Ward.

Lee, M. N. N. (1999). Education in Malaysia: Towards Vision 2020. School Effectiveness and School Improvement, 10(1), 86-98. http://dx.doi.org/10.1076/sesi.10.1.86.3514

Malaysia. (2010). Rancangan Malaysia Kesepuluh. Bab 5 Membangun dan mengekalkan modal insan bertaraf dunia. Retrieved from http://www.moe.gov.my

Markus, A., \& Kirpitchenko, L. (2007). Conceptualising Social Cohesion. In J. Jupp, J. Nieuwenhuysen, \& E. Dawson (Eds.), Social Cohesion in Australia (pp. 21-32).

Ministry of Education Malaysia. (2001). Education Development Plan for Malaysia. 2001-2010. Generating educational excellence through collaboration planning. Kuala Lumpur: Ministry of Education Malaysia.

Ministry of Education Malaysia. (2008). Pelan Induk Pembangunan Pendidikan 2006-2010: Bab 3 Pendidikan Kebangsaan: Melangkah ke Hadapan. Retrieved from http://www.moe.gov.my/tayang.php?laman=pipp\&unit=kementerian\&bhs=en

Ministry of Education. (2012). Laporan Awal Pelan Pembangunan Pendidikan Malaysia 2013-2025. Putrajaya: Kementerian Pelajaran Malaysia.

Mukherjee, H., \& Singh, J. S. (1983, June). The new primary school curriculum project: Malaysia. International Review of Education, 29(2), 247-257. Retrieved from http://www.springerlink.com/content/g67614k14m57rjp6/ http://dx.doi.org/10.1007/BF00598000

Mumbai University. (2012). Meaning, Scope and Functions of Philosophy of Education. Retrieved from http://www.mu.ac.in/myweb_test/ma edu/M.A.Edu.Philosophy.pdf

Navaratnam, R. (2012). National Education Blueprint needs more work. Retrieved September 12, 2012, from http://blog.limkitsiang.com/2012/09/12/national-education-bluepring-needs-more-work

Ong, H. S. (1952). Education for Unity in Malaya: An Evaluation of the Educational System of Malaya with Special Reference to the Need for Unity in its Plural Society. Penang: Malayan Educator.

Ong, P. L. (2008). Towards a More Engaging Pedagogy. Community, 1(1), 8-13.

Ong, P. L., \& Roovasini (Eds.). (2010). $3 R+1$ : education for intercultural understanding. Bangi: Institute of Ethnic Studies, UKM.

Pemandu. (2010). Government Transformation Roadmap: NKRA Education, Chapter 8 Improving student outcomes. Retrieved from http://www.pemandu.gov.my/index.php

Selvadurai, S. (2012). The Malaysian Education System. Paper presented at the $16^{\text {th }}$ Malaysian Education Summit 2012, organised by ASLI, 23-24 April 2012, Sunway Resort Hotel \& Spa, Bandar Sunway.

UNESCO. (2010). Ten things to know about EFA. Retrieved from http://www.unesco.org/en/efa/the-efa-movement/10-things-to-know-about-efa

United Nations Development Programme. (2005). Malaysia: Mencapai Matlamat Pembangunan Millennium. Kuala Lumpur: United Nations Development Programme. Retrieved from http://www.undp.org.my/uploads/files/MDG_advocacy_Malay.pdf

United Nations Development Programme. (2009). Millennium Development Goals 2 - Achieve Universal Primary Education. Retrieved from http://www.undp.org.my/uploads/mdg2.pdf

Wikipedia. (2009). The Razak Report. Retrieved from http://en.wikipedia.org/wiki/Razak_Report

Wikipedia. (2012). Malala Yousafzai. Retrieved from http://en.wikipedia.org/wiki/Malala_Yousafzai

\section{Copyrights}

Copyright for this article is retained by the author(s), with first publication rights granted to the journal.

This is an open-access article distributed under the terms and conditions of the Creative Commons Attribution license (http://creativecommons.org/licenses/by/3.0/). 